\title{
Evaluation of the quality of Dahi available in Sylhet Metropolitan City
}

\author{
S. Dey ${ }^{1}$, A. Iqbal ${ }^{1}$, A. Ara ${ }^{2}$ and M. H. Rashid ${ }^{3}$ \\ ${ }^{1}$ Department of Genetic Engineering and Biotechnology, Shahjalal University of Science and Technology, Sylhet, \\ ${ }^{2}$ Department of Dairy and Poultry Science, Sylhet Agricultural University, Sylhet and ${ }^{3}$ Departemnt of Dairy Science, \\ Bangladesh Agricultural University, Mymensingh-2202, Bangladesh
}

\begin{abstract}
The study was undertaken to evaluate the quality of Dahi available in Sylhet Metropolitan City. Dahi samples from five different Sweetmeat Shops namely Fulkoli, Banaful, Mohanlal, Modhuban and Shad were collected and analyzed. Significant difference in chemical (protein, fat, total solids, ash, acidity and $\mathrm{pH}$ ) and microbiological status was found among different Dahi samples. Of the five Dahi Brands examined, Fulkoli Brand Dhai had the highest protein content $(4.58 \pm 0.24)$ and Shad Brand Dahi had the lowest protein content $(4.01 \pm 0.17)$. Fat content was highest in Fulkoli Brand $(4.02 \pm 0.13)$ and lowest in Shad Brand $(2.10 \pm 0.21)$. The highest total solids content was found in Dahi of Shad Brand (38.00 \pm 2.23$)$ and lowest total solids content was found in Banaful Brand Dahi (32.02 $\pm 1.50)$. Highest Total Viable Count (log cfu/ml.) was recorded in the Dahi of Shad Brand (5.92 \pm 0.09$)$ and lowest Total Viable Count was recorded in Mohanlal Brand Dahi (5.84 \pm 0.06$)$. Coliform bacteria, Yeast and Mould were present in all the samples. From this experiment, it was found that Fulkoli Brand Dahi was the best in quality . Dahi of Banaful and Mohanlal were in $2^{\text {nd }}$ and $3^{\text {rd }}$ position in quality.
\end{abstract}

Keywords: Fermented milk, Evaluation, Chemical analysis, Microbial count, Total viable count

\section{Introduction}

In Bangladesh Dahi is a very popular fermented milk product. About $4 \%$ of the milk produced in Bangladesh is used for Dahi preparation (Mostafa, 1997). Mainly two types of Dahi are available in local markets here, sweetened/misti Dahi (sugar added) and sour Dahi and both are prepared by a traditional method using previously made Dahi (starter). Traditional method invariably involves production on a small scale, either in the consumer's household or in the sweetmeat-maker's shop in urban areas. In the household, milk is heated to boiling temperature until volume is reduced up to $15-20 \%$ and $8-10 \%$ sugar added (sweetened Dahi), cooled down to body temperature, inoculated 2-3\% starter and poured into earthenware and kept for curd formation overnight by wrapping woolen cloth or straw or jute bag to maintain warmth. In the shops, the method is more or less the same and Dahi is usually set in suitable containers (earthenware/ glass bottles/plastic cups) of the required capacity. Most of the producers are used earthenware for setting Dahi to firmness rather than glass bottles/ plastic cups. Earthenware is assisting to absorb and evaporate a little amount of moisture from the Dahi resulted more firmness. The quality and color of Dahi are varies from shop to shop and area to area depending by using the different proportions and compositional milk and color improving agents. Various means and methods are adopted in its preparation so there can be seen a lot of variations among the quality of products. Though, Dahi is prepared without any care of quality control and hygienic conditions and contain a lot of contaminants, which may be health hazards spontaneously. However, traditional fermented Dahi still enjoy loyal following in rural communities in Bangladesh and it is also used as a dessert served after typical Bangladeshi Polao dishes. In Bangladesh, Dahi are sold almost in open markets and kept on shelf at ambient temperature without cover on products. A few sellers of city areas are kept their products in refrigerators for prolonging storage and other kept their products at room temperature and they might be sold within short time (1-2 days) before deterioration of products. The present study was taken up with a view to evaluate the quality of available Dahi in Sylhet Metropolitan City.

\section{Materials and Methods}

This experimental attempt was made to evaluate the quality of Dahi available in local market of Sylhet town. The experiment was conducted for a period of 2 months starting from April to May, 2010. 


\section{Collection of Dahi}

Twenty five samples of five different Dahi brands were collected randomly from five different sweetmeat shops of the local markets under stringent hygienic conditions. Samples were brought to experimental site with the help of a large wide mouthed ice-pot, maintaining the temperature $4-5^{\circ} \mathrm{C}$. The size of the samples ranged from 150-200g packet in small size plastic pots. After collection, samples were stored in refrigerator at $5^{\circ} \mathrm{C}$ until analyzing.

\section{Chemical Analysis}

Acidity percentage was determined by titrating with N/10 sodium hydroxide solution using the procedure of Aggarwala \& Sharma (1961), Fat percentage was determined by Gerber method, Protein percentage was determined by Kjeldahal procedure as described by Aggarwala \& Sharma (1961), Total solids and Ash content of the Dahi samples were determined by oven drying method according to A.O.A.C. (2003). $\mathrm{pH}$ value was measured using digital $\mathrm{pH}$ meter equipped with combination glass electrode.

\section{Microbial count}

Microbial parameters (Total Viable Count, Coliform Count, Yeast and Mold Counts) were determined by the standard plate count method according to American Public Health Association (APHA). Plate Count Agar, Eosin Methylene Blue (EMB) agar and potato dextrose agar were used for total viable count, coliform count, and yeast and mold counts respectively. Plate count agar and sterile saline were prepared. The samples were transferred into sterile saline and each serile dilutions then put into plate and poured agar (10-15 ml.) and allowed for solidification. After solidified, the colonies were enumerated which plate having within 30-300 colonies. Potato dextrose agar was also prepared and adjusted to $\mathrm{pH}$ 3.5 by adding $10 \%$ tartaric acid solution. Serial dilutions and agar pouring method were followed the same procedure of plate count agar. Plates were kept at room temperature $\left(28-30^{\circ} \mathrm{C}\right)$ for 3-5 days. The molds and yeast colonies were enumerated. Eosin Methylene Blue (EMB) agar was also prepared. Serial dilutions and agar pouring method were followed the same procedure of plate count agar. After solidification of agar, the plates were inverted and placed in an incubator adjusted at $32^{\circ} \mathrm{C}$ for 24 hours. After incubation, dark red colonies were counted at least of diameter $0.5 \mathrm{~mm}$.

\section{Statistical analysis}

Data obtained from collected samples were analyzed statistically using SPSS 16.0 computer software.

\section{Results and Discussion}

\section{Chemical analysis}

Acidity: Acidity value for Dahi samples of Fulkoli, Banaful, Mohanlal, Modhuban and Shad Sweetmeat shop made Dahi were $0.77 \pm 0.05,0.68 \pm 0.04,0.81 \pm .10,0.76 \pm 0.03,0.79 \pm 0.03$ (Table 1). Significant differences were found $(p<0.01)$ in respect of acidity content of the samples. These results are in line with the findings of Ali et al. (2002). The highest acidity was that of Mohanlal Brand Dahi at $0.81 \pm .10 \%$ and the lowest acidity was that of Banaful Brand Dahi at $0.68 \pm 0.04 \%$. The Highest acidity of Mohanlal Brand Dahi might be due to uncontrolled incubation, postproduction handling and prolonging storage while Banaful Brand Dahi samples might be produced under controlled incubation and temperature or maintained a low temperature after production.

Fat: The percentage of fat of Fulkoli, Banaful, Mohanlal, Modhuban and Shad Sweetmeat shops made Dahi were $4.02 \pm 0.13,3.6 \pm 0.07,3.36 \pm 0.36,3.24 \pm 0.23$ and $2.10 \pm 0.21$ respectively (Table 1). Statistically analysis showed that fat content of different Dahi samples differ significantly $(p<0.01)$. Maximum fat percentage was seen in Fulkoli Dahi $(4.02 \% \pm 0.13)$ and minimum fat per cent was found in Shad Sweetmeat shop made Dahi (2.1 \pm 0.21$)$. The fat percentage of Dahi of Bangladesh was ranged 
from 3.00 to $4.75 \%$ (Rashid and Miyamoto 2005). The variation in fat content between different Dahi samples might be caused by lacking of quality control or standardization of milk for Dahi production, adulteration of milk etc. Long storage period might be results in variation of fat content among Dahi samples of different local Dahi Brands.

Protein: The results of protein content of different samples of Dahi collected from Sylhet Metropolitan city are depicted in Table 1 . It has been observed from the table that there was significant $(p<0.01)$ differences of protein content of Dahi. This result was in agreement with the results of Haj et al. (2007). It also agrees with the findings of Tamime and Deeth (1980) who concluded that the addition of milk powder raised the protein level of milk. These results are also in line with findings of Duitschaver and Arnott (1972), who reported that plain yoghurt was higher in protein content due to the absence of dilution effect. These results are not in line with findings of Shanley (1973) who found that the protein and ash contents of yoghurt decreased with the progress of storage period.

Ash: Ash content of different Dahi Brands is presented in Table 1. Average ash content for Fulkoli, Banaful, Mohanlal, Modhuban and Shad Sweetmeat Shop made Dahi were $0.93 \pm 0.06,1.03 \pm 0.17$, $1.22 \pm 0.07,1.16 \pm 0.21$ and $1.42 \pm 0.06$ respectively). Statistical analysis showed that there was significant difference $(p<0.01)$ within the ash content of different Dahi samples. Highest and lowest ash content was seen in Shad and Fulkoli Brand Dahi respectively. The findings of this study agree with the work of TARAKÇI and KÜÇÜKÖNER (2003) and Ali et al. (2002). This finding indicates the defect in Dahi production process. It also found that there was wide variation in case of ash (\%) among different Dahi samples. Ash content in Dahi samples varies might be due defects in standardization of milk, difference in concentration of milk, adulteration etc.

Total Solids: The mean percentage of Total Solids content of Fulkoli, Banaful, Mohanlal, Modhuban and Shad Sweetmeat Shop made Dahi were $36.03 \pm 1.31,32.02 \pm 1.50,34.81 \pm 1.70,33.39 \pm 2.35$ \& $38.0 \pm$ 2.23 respectively (Table 1$)$. Significant differences $(p<0.01)$ in Total Solids content were found among different Sweetmeat shops made Dahi. Highest Total Solids content was found in Shad sweat meat shop (38.0 \pm 2.23$)$ and lowest Total Solids percent was seen in Banaful sweat meat shop made Dahi (32.02 \pm 1.50). The difference in Total Solids content may be due to the difference in fat, protein, ash and sugar content of Dahi samples. From another study Adeyl (1998) also found similar result. In case of Dahi milk is used without subjecting to standardization leading to much variation as observed in total solids content of market Dahi samples (Younus et al., 2002).

Table 1. Chemical analysis of Dahi collected from Sylhet Metropolitan City

\begin{tabular}{|c|c|c|c|c|c|c|}
\hline Parameters & $\begin{array}{c}\mathrm{A} \\
\text { Mean } \pm \text { SD }\end{array}$ & $\begin{array}{c}\mathrm{B} \\
\text { Mean } \pm \text { SD }\end{array}$ & $\begin{array}{c}\mathrm{C} \\
\text { Mean } \pm \text { SD }\end{array}$ & $\begin{array}{c}\text { D } \\
\text { Mean } \pm S D\end{array}$ & $\begin{array}{c}\text { E } \\
\text { Mean } \pm S D\end{array}$ & $\begin{array}{c}\text { Level of } \\
\text { significance }\end{array}$ \\
\hline Acidity (\%) & $0.77 \pm 0.05$ & $0.68 \pm 0.04$ & $0.81 \pm .10$ & $0.76 \pm 0.03$ & $0.79 \pm 0.03$ & $* *$ \\
\hline Fat $(\mathrm{g} / \mathrm{kg})$ & $40.20 \pm 1.30$ & $36.0 \pm 0.70$ & $33.60 \pm 3.60$ & $32.40 \pm 2.30$ & $21.00 \pm 2.10$ & $* *$ \\
\hline Protein $(\mathrm{g} / \mathrm{kg})$ & $45.80 \pm 2.40$ & $46.60 \pm 1.80$ & $46.00 \pm 2.50$ & $43.20 \pm 1.90$ & $40.10 \pm 1.70$ & $* *$ \\
\hline Ash $(\mathrm{g} / \mathrm{kg})$ & $9.30 \pm 0.60$ & $10.30 \pm 1.70$ & $12.20 \pm 0.70$ & $11.60 \pm 2.10$ & $14.20 \pm 0.60$ & $* *$ \\
\hline $\begin{array}{c}\text { Total solids } \\
(\mathrm{g} / \mathrm{kg})\end{array}$ & $360.30 \pm 13.10$ & $320.20 \pm 15.00$ & $348.10 \pm 17.00$ & $333.90 \pm 23.50$ & $380.00 \pm 22.30$ & \\
\hline $\mathrm{pH}(\%)$ & $4.65 \pm 0.02$ & $4.74 \pm 0.03$ & $4.67 \pm 0.04$ & $4.59 \pm 0.01$ & $4.61 \pm 0.01$ & \\
\hline
\end{tabular}

( $A=$ Fulkoli Sweetmeat Shop, B= Banaful Sweetmeat Shop, $C=$ Mohanlal Sweetmeat Shop, $D=$ Modhuan Sweetmeat Shop, E= Shad Sweetmeat Shop)

** $0.01 \%$ level of significance

pH: The Dahi samples of different commercial brands collected from Sylhet Market were analyzed for pH value and results are presented in Table 1. The mean $\mathrm{pH}$ value in commercial brands Dahi supplied by Modhuban Sweetmeat Shop was minimum (4.59 \pm 0.01$)$, and Banaful Brand Dahi was maximum (4.74 \pm 0.03$)$. However $\mathrm{pH}$ value of Dahi marketed by Fulkoli and Shad Brands were with mean $\mathrm{pH}$ value averaged $4.65 \pm 0.02,4.67 \pm 0.04$ and $4.61 \pm 0.01$ respectively. This result agrees with those reported by Antunes et al. (2004). While comparison was made between different commercial brands of Dahi 
marketed at Sylhet, it was observed that there was significant differences $(p<0.01)$ among the $\mathrm{pH}$ values of different Dahi brands. Increase in protein content might results increase in $\mathrm{pH}$ value. $\mathrm{pH}$ value ranging 3.8-4.0 is desirable for Dahi because vegetative cells of pathogenic bacteria can't grow or survive under such condition (Rashid and Miyamoto, 2005).

\section{Microbial count}

Total Viable Count : The Total Viable Count per ml. for Fulkoli, Banaful, Mohanlal, Modhuban and Shad Sweetmeat Shops made Dahi were $5.85 \pm 0.04,5.86 \pm 0.05,5.84 \pm 0.06,5.87 \pm 0.04$ and $5.92 \pm 0.09(\log$ cfu/ml.) respectively (Table 2 ). It was revealed that there was no significant difference among Dahi samples. Average highest Total viable count for Dahi samples of Shad Sweetmeat Shop was recorded as $5.92 \pm 0.09$ and lowest Total viable count for Dahi samples of Mohanlal Sweetmeat Shop was recorded as $5.84 \pm 0.06$. The present investigation partially supported by the result of Adeyl (1998) and Haj et al. (2007). The variations in Total viable count in different Dahi samples might be due to the use of undefined wild starter culture in improper ratio and amount. It also contains heterogeneous mixture of lactic acid bacteria, as a result Total Viable Count in Dahi samples varies.

Coliform count: The average Coliform count per ml. of Fulkoli, Banaful, Mohanlal, Modhuban and Shad Sweetmeat shop made Dahi were $1.98 \pm 1.11,2.41 \pm 0.27,2.52 \pm 0.18,2.85 \pm 0.09$ and $2.73 \pm 0.17$ respectively (Table -2$)$. Average highest Coliform count per $\mathrm{ml}$. (2.85 \pm 0.09$)$ was found in Modhuban Sweetmeat Shop made Dahi and lowest Coliform count per ml. $(1.98 \pm 1.11)$ was found in Fulkoli Sweetmeat Shop made Dahi. The existence of Coliform bacteria is the indication of contamination in Dahi samples. This might be result of the poor hygienic condition of the production period. The possible sources of contamination of product are uncleaned hands of manufacturers, poor quality of water used to clean earthen pots and exposure of the product to open air during setting of curd. The findings of this experiment partially support the findings of Islam (1999) and Alam (1999). Islam (1999) reported that Coliform count per $\mathrm{ml}$. of laboratory made Dahi was (144.02 to 400.66), log value (2.64 \pm 2.05$)$. Alam (1999) found that the Coliform count in Dahi made from cow milk was (100 to 500), log value (1.81 \pm 1.14$)$.

Yeast Count: Results corresponding to the Yeast Count of different Dahi samples are shown in (Table 2). The average Yeast count per ml. of Fulkoli, Banaful, Mohanlal, Modhuban and Shad Sweetmeat shop made Dahi were $2.97 \pm 0.14,3.02 \pm 0.10,3.11 \pm 0.10,3.33 \pm 0.05$ and $3.28 \pm 0.05$ (log cfu $/ \mathrm{ml}$.) respectively. Mean average Yeast count per $\mathrm{ml}$. was $3.15 \pm 0.16(\log \mathrm{cfu} / \mathrm{ml}$.). Highest Yeast count was reported in the Dahi of Modhuban Sweetmeat shop (3.33 \pm 0.05$)$ and lowest Yeast count per ml. was reported in the Dahi of Fulkoli Sweetmeat shop Dahi $(2.97 \pm 0.14)$. Presence of Yeast was the indication of contamination. The Yeast colonies were observed in all the Dahi samples. This contamination might be happened by traditional culture (starter) or contamination of post production or handling defect. TARAKÇI and KÜÇÜKÖNER (2003) also reported the similar findings who found that the Yeast count per ml. of different fruit flavored yogurt was 125 to 776 , log value was 2.10 to 2.89 .

Table 2. Microbial profiles of Dahi samples collected from Sylhet Metropolitan City

\begin{tabular}{|c|c|c|c|c|c|c|}
\hline Parameters & $\begin{array}{c}\mathrm{A} \\
\text { Mean } \pm S D\end{array}$ & $\begin{array}{c}\text { B } \\
\text { Mean } \pm S D\end{array}$ & $\begin{array}{c}\text { C } \\
\text { Mean } \pm \text { SD }\end{array}$ & $\begin{array}{c}D \\
\text { Mean } \pm S D\end{array}$ & $\begin{array}{c}E \\
\text { Mean } \pm S D\end{array}$ & $\begin{array}{c}\text { Level of } \\
\text { significance }\end{array}$ \\
\hline $\begin{array}{c}\text { Total viable } \\
\text { count } \\
\text { (log cfu/ml) }\end{array}$ & $5.85 \pm 0.04$ & $5.86 \pm 0.05$ & $5.84 \pm 0.06$ & $5.87 \pm 0.04$ & $5.92 \pm 0.09$ & N/S \\
\hline $\begin{array}{c}\text { Coliform count } \\
\text { (log cfu/ml) }\end{array}$ & $1.98 \pm 1.11$ & $2.41 \pm 0.27$ & $2.52 \pm 0.18$ & $2.85 \pm 0.09$ & $2.73 \pm 0.17$ & $\star \star$ \\
\hline $\begin{array}{l}\text { Yeast count } \\
\text { (log cfu/ml) }\end{array}$ & $2.97 \pm 0.14$ & $3.02 \pm 0.10$ & $3.11 \pm 0.10$ & $3.33 \pm 0.05$ & $3.28 \pm 0.05$ & *夫 \\
\hline $\begin{array}{l}\text { Mould count } \\
(\log \mathrm{cfu} / \mathrm{ml})\end{array}$ & $0.75 \pm 0.70$ & $0.20 \pm 0.44$ & $0.46 \pm 0.63$ & $1.21 \pm 0.63$ & $1.36 \pm 0.29$ & $\star \star$ \\
\hline
\end{tabular}

${ }^{* *} 0.01 \%$ level of significance, N/S= Not Significant) 
Mould Count: The average Mould counts per ml. of different Dahi samples have been shown in Table 2. A significant difference was found in respect of Mould count per $\mathrm{ml}$. of different Dahi samples. The presence of Mould in Dahi might be due to contamination of milk from its collection to processing of milk for Dahi production. The present findings of Mould count per $\mathrm{ml}$. are similar to the findings of Rashid and Miyamoto (2005). They investigated Dahi samples from different district of Bangladesh and reported that the Mould count per ml. of Dahi samples ranged 0 to 75 , log value 0 to 1.87 .

\section{Conclusion}

From the present study it can be concluded that the Dahi available in Sylhet city is not maintained the proper quality. A comprehensive research work is still required to set a standard for commercial production of Dahi in Bangladesh to have uniformity and superiority in its organoleptical, chemical and microbiological quality.

\section{References}

A.O.A.C. 2003. Official methods of analysis of the Association of Official Analytical Chemists. 15th edition. Washington, DC, Association of Official Analytical Chemists.

Aggawala, A.C. and Sharma, 1961. A Laboratory Manual of Milk Inspection. Bombay, Calcutta, New Delhi, India.

Adeyl, F.M. 1998. Studies on the physical, chemical and microbiological qualities of misti Dahi of different districts of Bangladesh. M.S. Thesis, Department of Dairy Science, Bangladesh Agricultural University, Mymensingh.

Ali, M.Y., Islam, M.A., Alam, M.J. and Islam, M.N. 2002. Quality evaluation of laboratory made Dahi and Dahi available in local market in Mymensingh of Bangladesh. Pakistan J. of Biological Sci. 5(3): 343-345.

Alam, K. 1999. Quality evaluation of dahi made from cow, goat and buffalo milk. M .S. Thesis, Department of Dairy Science, Bangladesh Agricultural University, Mymensingh.

Antunes, A.E.C., Antunes, A. J. and Cardello, H.M.A.B. 2004. Chemical, physical microstructural and sensory properties of set fatfree yoghurts stabilized with protein concentrate. Milchwissenschaft, 59 (3/4): 161-165.

Duitschaver, C.L. and Arnott, D.R. 1972. Quality evaluation of yoghurt produced commercially in Ontario. J. Milk Food Technology, 35(3): 173-175.

Haj, H.M., Osman, A.O., Owni, El. and Ibtisam, E.M. El. 2007. Assessment of Chemical and Microbiological Quality of Stirred Yoghurt in Khartoum State, Sudan. Research Journal of Animal and Veterinary Sciences, 2: 56-60.

Islam, M.D.S. 1999. A comparative study on the quality of Laboratory prepared and Local Village Market Dahi. A M.S. Thesis, Dept. of Dairy Science, Bangladesh Agricultural University, Mymensingh.

Mostafa, MD. 1997. A study on the preparation of fruit Dahi (yogurt). A M.S. Thesis. Dept. of Dairy Sci, Mymensingh Agricultural University, Mymensingh. Bangladesh.

Rashid, M.H. and Miyamoto, T. 2005. Quality evaluation of traditional fermented milk "Dahi" in Bangladesh. Milk Science., 54(1): 29-36.

Shanley, M.K. 1973. Analysis of free sugars in yoghurt. Aust. J. Dairy Technology, 28(2): 58-60.

Tamime, A.Y. and Deeth, H.C. 1980. Yoghurt: technology and biochemistry. J. Food Prot., 43: 939-977.

TARAKÇI, Z. and KÜÇÜKÖNER, E. 2003. Physical, Chemical, Microbiological and Sensory Characteristics of Some Fruit-Flavored Yoghurt. YYÜ Vet Fak Derg 2003, 14 (2):10-14.

Younus, S., Masud, T. and Aziz, T. 2002. Quality Evaluation of Market Yoghurt /Dahi. Pakistan Journal of Nutrition, 1 (5): $226-230$. 